\title{
GENETIC ANALYSIS OF SOME PRODUCTIVE AND REPRODUCTIVE TRAITS OF FIRST LACTATION OF FRIESIAN CATTLE RAISED IN EGYPT
}

Shalaby, N. A. ${ }^{1}$; A. S. A. El-Barbary ${ }^{2}$; E. Z. M. Oudah ${ }^{1}$ and M. Helmy ${ }^{1}$

${ }^{1}$ Dept. of Animal Production, Fac. Agric., Mans. Univ.

PC: 35516, Mansoura, Egypt.

2 Dept. of Animal Production, Fac. Agric., Alex. Univ.

PC: 21545, Egypt.

\begin{abstract}
Data used in this investigation were collected from 4370 records relevant to 874 purebred Friesian cows which belong to Shobratana Animal Production Society, located in the north part of Delta region near Tanta city in Egypt. These cows were daughters of 43 sires. The records used covered the period from 1985 to 2003 . The following six productive and reproductive traits of the first lactation were analyzed: Total Milk Yield (TMY, kg), dry period (DP, day), lactation length (LL, day), days open (DO, day), calving interval, (Cl, month) and age at first calving (AFC, month).sire random effect and month and year fixed effect. Data were analyzed using Linear Mixed Model Least Squares and Maximum Likelihood (LSMLMW) computer program of Harvey (1990). The overall means of TMY, DP and LL were $5387 \mathrm{~kg}, 72.9$ days and 327 days, respectively. The overall means of $\mathrm{Cl}$, DO and AFC were 13.4 month, 121 days and 27.8 month, respectively. Heritability estimates for TMY, DP, LL, CI, DO and AFC were $0.141 \pm 0.074,0.109 \pm 0.069,0.040 \pm 0.057,0.104 \pm 0.068,0.202 \pm 0.084$ and $0.217 \pm 0.087$ respectively. The ranges of breeding values of all sires in the pedigree for TMY, DP, LL, DO and Cl were $685 \mathrm{~kg}, 18$ day, 8.15 day, 48.2 day and 1.05 month, respectively. Spearman rank correlations and Pearson correlations among estimated breeding values of all sires in pedigree provided by the genetic analysis ranged between -0.712 to 0.907 . The objectives of the present study were: 1) to estimate some genetic and non-genetic factors affecting productive and reproductive traits, 2) to estimate genetic and phenotypic parameters for these traits and 3) to estimate breeding values for sire Friesian cows in this farm. Rank correlations of animals between traits were the lowest for reproduction traits. It could be concluded that improving the environmental conditions will improve these traits.

Keywords: Friesian cows, Genetic parameters, Breeding value, BLUP, Egypt
\end{abstract}

\section{INTRODUCTION}

The success of selection for milk production has contributed to the domination of the Friesian breed around the world. In Egypt, dairy industry represents $35 \%$ of the total animal production sector. During the last two decades, considerable emphasis had been placed upon the importance of Friesian cattle in Egypt for milk production, accordingly the number of large Friesian herds had increased either in the governmental or commercial farms through importation from Europe and USA (Shalaby et al., 2001). Main reasons of low productivity of farm animals are; non-descript breed, poor management, lack of nutrition, lack of resources, low inputs; inadequate 
Shalaby, N. A. et al.

artificial insemination service and diseases. These causes lead to low average milk production, late age at first calving, delayed conception, impaired fertility, long calving intervals (Khan et al., 2008). Low reproductive efficiency due either to delayed first service, missed estrus, or multiple services per conception continues to be a major problem in dairy herds. Insufficient reproductive performance results in excessively late age at first calving and long lactations. Both are costly to the dairy producers because of the veterinarian breeding expense, high reproductive replacement costs and fewer calves being born (Oudah et al., 2001). The objectives of the present study were: 1) to estimate some genetic and non-genetic factors affecting productive and reproductive traits, 2) to estimate genetic and phenotypic parameters for these traits and 3 ) to estimate breeding values for sire Friesian cows in this farm.

\section{MATERIAL AND METHODS}

Data: Data used in this investigation were collected from 4370 records relevant to 874 purebred Friesian cows which belong to Shobratana Animal Production Society, located in the North Part of Delta region near Tanta city in Egypt. These cows were daughters of 43 sires. The records used covered the period from 1985 to 2003 . The following six productive and reproductive traits of first lactation were analyzed: total milk yield (TMY, kg ), dry period (DP, day ), lactation length (LL,day), days open, defined as the interval from calving to conception, (i.e. the number of days between parturition and the insemination that resulted in a pregnancy) (DO, day), first calving interval, defined as the number of days occurring between first calving and $2^{\text {nd }}$ calving $(\mathrm{Cl}$, day) and age at first calving, defined as number of months between date of birth and date of the first parturition of a cow (AFC, month).

Management: Animals were housed free in shaded open yards covered with 3.5-4 meters high roofs, grouped according to their average daily milk yield and were fed adlibitum on berseem (Trifolium alexandrinum) and rice straw in addition concentrates feed mixture from December to April (green season) and cows were fed daily on ration consisting of cotton seed cakes, barley wheat and rice bran,(not less than $18 \%$ crude protein from May to November (dry season). Mineral mixture bricks were offered adlibtium as lick salt in front animals, and on balanced ration of a concentrates according to their production and weight. Rice straw was offered adlibitum and sometimes limited amount clover hay when available. Water was also available freely. In general, cows were artificially inseminated during the first two heats which occurred after 60 days postpartum using imported frozen semen from USA and Canada. Heifers were artificially inseminated for the first time in the first two heats once they attained $350 \mathrm{~kg}$ of live body weight or $18-22$ months of age. Pregnancy diagnoses were carried out routinely at 60 days after service by rectal palpation. If conception did not occur or the cows were seen in estrus, the cows were inseminated again. The cows were machine milked 
three times a day at $04.00,12.00$ and $19.00 \mathrm{~h}$. The calves born were artificially suckled from birth to weaning excluding colostrums' period.

Statistical analysis: Data were analyzed using Linear Mixed Model Least Squares and Maximum Likelihood (LSMLMW) computer program of Harvey (1990). Three models of statistical analysis were used for studying factors affecting some productive traits, i.e. total milk yield (TMY, kg ), dry period (DP, day ), lactation length ( $L L$,day), two reproductive traits: i.e., days open (DO, day) and calving interval ( $\mathrm{Cl}$, month) and age at first calving(AFC, month).

1) The following first mixed model was used to analyze the productive traits:

$Y_{i l m}=\mu+S_{i}+M_{1}+Y_{m}+b L_{1}\left(x_{1}-\bar{X}_{1}\right)+b Q_{1}\left(x_{1}-\bar{X}_{1}\right)^{2}+b_{2}\left(x_{2}-\bar{X}_{2}\right)+b Q_{2}\left(x_{2}-\bar{X}_{2}\right)^{2} e_{i l m}$

Where:

$\mathrm{Y}_{\mathrm{ilm}} \quad=$ the individual observation,

$\mu \quad=$ the overall mean,

$\mathrm{Si}_{\mathrm{i}} \quad=$ the random effect of the $i^{\text {th }}$ sire, $i=1$ to 43 ,

$\mathrm{Ml}_{\mathrm{l}} \quad=$ the fixed effect of the $\mathrm{I}^{\text {th }}$ month of calving; $I=1,2,3, \ldots \ldots$, and 12 ( January, February, March..... and December),

$\mathrm{Y}_{\mathrm{m}} \quad=$ the fixed effect of the $\mathrm{m}^{\text {th }}$ year of calving, $\mathrm{I}=1,2,3, \ldots ., 19$ (from 1985 to 2003),

$b_{1} \& b Q_{1}=$ Partial linear and quadratic regression coefficients, respectively for productive traits on age at first calving (months).

$\mathrm{bL}_{2} \& \mathrm{bQ}_{2}=$ partial linear and quadratic regression coefficients, respectively for productive traits on days open (days),

$\mathrm{x}_{1}=$ age at first calving(AFC) of cow, $\bar{X}_{1}$ average AFC, month;

$\mathrm{X}_{2}=$ days open (DO) of cow, $\bar{X}_{2}$ average $\mathrm{DO}$ (day); and

e $\mathrm{eilm}_{\mathrm{a}} \quad=$ Residual term assumed to be random and distributed as a normal distribution with mean zero and variance $\sigma^{2} e$.

2) The following second mixed model was used to analyze the reproductive traits:

$Y_{i l m}=\mu+S_{i}+M_{1}+Y_{m}+b L_{1}\left(x_{1}-\bar{X}_{1}\right)+b Q_{1}\left(x_{1}-\bar{X}_{1}\right)^{2}+b L_{2}\left(x_{2}-\bar{X}_{2}\right)+b Q_{2}\left(x_{2}-\bar{X}_{2}\right)^{2}+e_{i l m}$

Where all definitions as mentioned above except for:

$\mathrm{bL}_{2} \& \mathrm{bQ}_{2}=$ partial linear and quadratic regression coefficients, respectively for reproductive traits on total milk yield $(\mathrm{kg})$ and $\mathrm{x}_{2}=\mathrm{TMY}$ of cow and $\overline{\mathrm{X}}_{2}$ is average TMY $(\mathrm{kg})$.

3) The following third mixed model was used to analyze the age at first calving:

$Y_{i l m}=\mu+S_{i}+M_{i l}+Y_{m}+e_{i l m}$

Where all definitions as mentioned above

Heritability estimates $\left(h^{2}\right)$ were computed by the paternal half-sib method according to formula outlined by Harvey (1990).

$h^{2}=4 \sigma^{2} s /\left(\sigma^{2} s+\sigma^{2} e\right)$

Estimation of sire transmitting ability (ETA's): The transmitting abilities of sires with at least 10 daughters were examined, and consequently 
Shalaby, N. A. et al.

the total number of sires used in estimation of ETA's was only 43 sires. Siretransmitting ability (ETA) for different traits was estimated by Best Linear Unbiased prediction (BLUP). Data of the first lactation records were used for estimating BLUP values; one set of cross-classified non interacting random effect (sire) is absorbed according to Harvey (1990) where BLUP estimates for random sire effects absorbed by maximum likelihood were obtained. Rank correlation coefficients among sire transmitting abilities (ETA's) for different traits were estimated using the Spearman formula (Snedecor and Cochron, 1956).

$$
Y=X f+Z s+W b+e
$$

Where:

$Y=a$ vector of observations for each trait,

$X=a$ known fixed design matrix,

$f=$ an unknown vector of fixed effects representing the mean of farm, origin and month and year of calving,

$\mathbf{Z}=\mathbf{a}$ known design matrix,

$\mathbf{s}=$ an un-observable vector of random sire effects,

$\mathrm{W}=\mathrm{a}$ vector of covariate variables (independent variables), age at first calving and Days open or total milk yield,

b = a vector of partial regression coefficient of $Y$ on $w$,

$\mathrm{e}=$ An un-observable random vector of error with mean and variancecovariance matrix $\mid \sigma^{2} e$.

Where:

$K=\left(4 h^{2}\right) / h^{2}$, for each trait was added to the diagonal of sire effects in the matrix; $h^{2}$ is the heritability estimate.

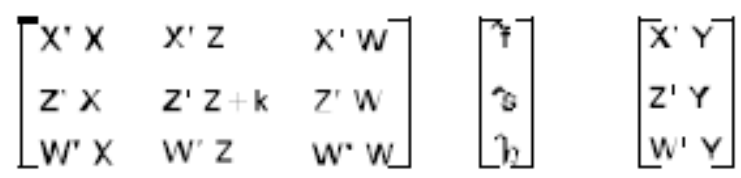

\section{RESULTS AND DISCUSSION}

Overall means, standard deviations (SD) and coefficients of variation (CV $\%)$ are shown in Table 1. The present overall mean of TMY was $5387 \mathrm{~kg}$ similar results were $(5283 \mathrm{~kg})$ found by Tag El-Dein (1997) working with another set of Friesian cows at the same farm and much higher than the published estimates on Friesian cattle in Egypt $2655 \mathrm{~kg}$ by Oudah and Zainab (2010), $3936 \mathrm{~kg}$ by El-Awady and Oudah (2011) and $2871 \mathrm{~kg}$ by Khattab and Sultan, 1990) and higher than those obtained by Khattab and Atil (1999) and Oudah et al. (2000) being 3709 and $3475 \mathrm{~kg}$, respectively. And with $3710 \mathrm{~kg}$ that obtained by Tadesse et al (2010) for Friesian in Ethiopia, $5905 \mathrm{~kg}$ that found by Ajili et al (2007) in Tunis, $4489 \mathrm{~kg}$ that reported by Ahmed et al 
(1997) in Libya. The present overall mean of DP (72.9 days) was shorter than that reported by Oudah et al. (2001) on Friesian cattle in Egypt (79.3 days). But it was longer than that obtained by Khattab and Atil (1999) being 65 days. The present overall mean of LL was 327 days. This length fell within the range reported by Skalicki and Latinovic (1990) who recorded almost similar results (344 days) for LL in Friesian cows in India. However a shorter mean (291.86 days) was stated by Sattar et al (2005). The overall means of $\mathrm{DO}$ and $\mathrm{Cl}$ reported in the present study were 121 days and 13.4 month, respectively (Table 1 ). These values were lower than the estimates (141 and 422 days, respectively) reported by Shalaby et al. (2001) on a similar Friesian herd in Egypt. The overall mean of AFC was 27.8 months (Table 1). Higher than estimate (27.1 months) of AFC of Friesian cattle in commercial herds in Egypt was depicted by Sadek et al. (1994). In the present study, the coefficients of variations (CV \%) ranged from 13.1 for AFC to $71.8 \%$ for DP. Such large coefficients of variation are indicative leaders for opportunities for improvement in these traits. The differences between our findings and other investigators may be related to genetic differences between breeds, climatic conditions, differences in statistical models, managerial practices and/or feeding systems.

Table (1): Overall mean, standard deviation (SD) and coefficients of variation (CV \%) of Productive and Reproductive traits for first lactation of Friesian cow.

\begin{tabular}{|c|c|c|c|}
\hline Productive trait: & Mean & SD & CV\% \\
\hline Total Milk Yield (TMY kg) & 5387 & 2021 & 37.5 \\
\hline Dry Period (DP day ) & 72.9 & 52.4 & 71.9 \\
\hline Lactation Length (LL day) & 327 & 67.8 & 20.7 \\
\hline \multicolumn{4}{|c|}{ Reproductive trait: } \\
\hline Calving Interval (CL month ) & 13.4 & 2.96 & 22.1 \\
\hline Days Open (DO day) & 121 & 71.2 & 58.8 \\
\hline Age at First Calving (AFC month ) & 27.8 & 3.64 & 13.1 \\
\hline
\end{tabular}

Heritability and correlations: productive traits: Heritability estimates \pm standard errors (SE), genetic correlations \pm standard errors (SE) (above diagonal), environmental and phenotypic correlations for Productive and Reproductive traits for first lactation of Friesian cows are presented in Table 2. Heritability estimate for TMY reported in the present study $(0.141 \pm 0.074)$ was lower than that obtained in other countries by Swalve and Van Vleck (1987) working on Holstein Friesian cattle being 0.32. From the heritability estimates obtained in the present study for TMY, DP, and LL, it could be concluded that the low heritability estimates are enough to allow genetic improvement in milk production traits, which could be achieved through selection. Badawy and Oudah (1999) and Oudah et al. (2000) came to the same conclusion. Concerning the heritability estimate of DP obtained in the present study $(0.109 \pm 0.069)$, high result $(0.02)$ was found also by Salem and Abdel Raouf (1999) working on Holstein Friesian cattle in Egypt. The present low heritability estimate of DP indicates that the major part of variation in this trait is due to the non-genetic factors and great improvement could be 
achieved in this trait by improving management systems. The present genetic correlation coefficients between TMY and DP was negative $(-0.545)$ and between TMY and LL (1.522) was high and positive (Table 2). The higher and positive genetic correlation coefficient among TMY and LL indicates that selection for TMY will improve the other traits. Similar results were found by Tag El-Dein (1997) and Oudah et al. (2000). The present phenotypic correlation coefficient between TMY and DP was -0.02 and that between TMY and LL (0.160) was positive. These results are in the agreement, in most cases, with those reported by Khattab and Sultan (1990) and Tag ElDein (1997) on Friesian cattle in Egypt. The environmental correlation coefficients among all traits were generally less than the values of genetic correlation coefficients (Table 2) which may be due to more contribution of additive genetic deviation.

Table (2): Heritability estimates \pm standard errors (SE) (on diagonal), genetic correlations \pm standard errors (SE) (above diagonal), environmental (between parentheses) and phenotypic correlations (below diagonal) for factors affecting Productive and Reproductive traits for first lactation of Friesian cow.

\begin{tabular}{|c|c|c|c|}
\hline Productive traits: & TMY & DP & LL \\
\hline TMY & $0.141 \pm 0.074$ & $\begin{array}{c}-0.545 \pm 0.446 \\
(0.053)\end{array}$ & $\begin{array}{c}1.522 \pm 0.983 \\
(0.051)\end{array}$ \\
\hline DP & -0.021 & $0.109 \pm 0.069$ & $\begin{array}{c}-1.370 \pm 1.527 \\
(-0.449)\end{array}$ \\
\hline LL & 0.160 & -0.505 & $0.040 \pm 0.057$ \\
\hline Reproductive traits: & $\mathrm{Cl}$ & DO & AFC \\
\hline Cl & $0.104 \pm 0.068$ & $\begin{array}{c}1.046 \pm 0.093 \\
(0.775)\end{array}$ & ------- \\
\hline DO & 0.807 & $0.202 \pm 0.084$ & ---------- \\
\hline AFC & ---------------' & ----------- & $0.217 \pm 0.087$ \\
\hline
\end{tabular}

Reproductive traits: Heritability estimates ( \pm SE) based on paternal half-sibs for reproductive traits as well as genetic, phenotypic and environmental correlation coefficients between them are presented in Table 2. The lower heritability estimates of $\mathrm{DO}(0.202 \pm 0.084), \mathrm{Cl}(0.104 \pm 0.068)$ and AFC $(0.217 \pm 0.087)$ indicate that selection for these traits would not be effective in bringing about genetic improvement, therefore improving the environmental and managerial conditions should lead to considerable improvement in these traits. The present lower heritability estimates for both $\mathrm{DO}$ and $\mathrm{Cl}$ were confirmed previously by many authors under Egyptian conditions such as Salem and Abdel-Raouf (1999). The present genetic and phenotypic correlation coefficients between $\mathrm{DO}$ and $\mathrm{Cl}(1.046)$ and 0.807 , respectively) were positive and highly significant (Table 2). Lower genetic and phenotypic correlation coefficients were found by Salem and Abdel-Raouf (1999) being 0.64 and 0.82 , respectively. Genetic and phenotypic correlations among Productive and Reproductive traits for first lactation of Friesian cow were given in Table 3. The genetic and phenotypic correlation coefficients between $\mathrm{Cl}$ and TMY were- 0.193 and 0.207 , respectively. And those between DO and DP (0.583 and 0.425 respectively) were positive and also the genetic and phenotypic between AFC and LL were 1.47 and -0.004 , respectively. 
Table (3): Genetic correlations \pm standard errors (SE) and phenotypic correlations (between parentheses) among productive and reproductive traits for first lactation of Friesian cow.

\begin{tabular}{|l|c|c|c|}
\hline Traits & TMY & DP & LL \\
\hline CI & $-0.193 \pm 0.499$ & $0.720 \pm 0.288$ & $0.566 \pm 0.408$ \\
& $(0.207)$ & $(0.564)$ & $(0.747)$ \\
\hline DO & $-0.180 \pm 0.399$ & $0.583 \pm 0.288$ & $0.869 \pm 0.213$ \\
& $(0.221)$ & $(0.425)$ & $(0.737)$ \\
\hline AFC & $0.651 \pm 0.337$ & $-0.788 \pm 0.338$ & $1.47 \pm 0.668$ \\
& $(0.098)$ & $(-0.033)$ & $(-0.004)$ \\
\hline
\end{tabular}

\section{Estimated breeding values:}

Minimum and maximum for breeding values for different studied traits are presented in Table 4. The ranges of all animals in the pedigree for TMY, DP, LL, DO and $\mathrm{Cl}$ were $685 \mathrm{~kg}, 18$ day, 8.15 day, 48.2 day and 1.05, month respectively. The present results indicated that there was wide range of breeding values for all studied traits. The results similar by Oudah and Zainab (2010) for TMY and LL were $559 \mathrm{~kg}$ and 9.85 day respectively.

Table (4): Minimum and maximum for breeding values for different studied traits.

\begin{tabular}{|l|c|c|c|}
\hline \multicolumn{1}{|c|}{ Trait } & Min & Max & Range \\
\hline \multicolumn{3}{|c|}{ Productive trait: } \\
\hline TMY (kg) & -299 & 386 & 685 \\
\hline DP (day) & -9.76 & 8.24 & 18.0 \\
\hline LL (day) & -3.35 & 4.80 & 8.15 \\
\hline \multicolumn{4}{|c|}{ Reproductive trait: } \\
\hline DO (day) & -26.6 & 21.6 & 48.2 \\
\hline Cl (month) & -0.56 & 0.48 & 1.05 \\
\hline
\end{tabular}

Correlations between estimated breeding values:

Spearman rank correlations and Pearson correlations between EBVs for studied traits obtained for all animals in the pedigree are presented in Table 5. Correlations between estimated breeding values of all animals in pedigree (sires) provided by the genetic analysis ranged between 0.712 to 0.907 . Rank correlations of animals between traits were the lowest for reproduction traits. Oudah and Zainab (2010) and Shalaby (2005) obtained similar results.

Table (5): Spearman rank correlations (above diagonal) and Pearson correlations (below diagonal) among breeding values of different studied traits.

\begin{tabular}{|l|c|c|c|c|c|}
\hline Trait & TMY & DP & LL & DO & Cl \\
\hline TMY & & -0.258 & 0.451 & -0.250 & -0.211 \\
\hline DP & -0.274 & & -0.712 & 0.088 & 0.176 \\
\hline LL & 0.452 & -0.716 & & -0.231 & -0.142 \\
\hline DO & -0.375 & 0.089 & -0.204 & & 0.907 \\
\hline $\mathbf{C l}$ & -0.351 & 0.202 & -0.083 & 0.887 & \\
\hline
\end{tabular}




\section{CONCLUSION}

The low heritability of some traits studied indicated that the major part of the variation in these traits was environmental and selection may not prove effective in bringing about genetic improvement in these traits. Therefore, better management can play a major role in improving these traits.

\section{REFERENCES}

Ahmed,M.K.A, Kharoofa, A.D. S, Salhab, S. A and Zoied, A. A. (1997). Comparative performance of imported and homebred Holstein Friesian cows. Almukhtar for science, (3), 9-21

Ajili, N, Rekik, A, Gara Ben and Bouraoui, R. (2007). Relationships among milk production, reproductive traits, and herd life for Tunisian HolsteinFriesian cows. African Journal of Agricultural Research, 2 (2), 047-051.

Badawy, L. and E.Z.M. Oudah, (1999). A comparison between two different methods of estimating sire transmitting ability of some milk traits in a herd of Friesian cattle in Egypt. J. Agric. Sci. Mansoura Univ., 24: 4613-4624.

El-Awady and Oudah (2011). Genetic and Economic Analysis for the Relationship between Udder Health and Milk Production Traits in Friesian Cows Asian-Aust. J. Anim. Sci. 24(11):1514-1524

El-keraby, F. and Aboul-Ela, M. B. (1982). A study of some non-genetic factors affecting postpartum reproductive performance in Friesian cows. Tropical Animal Production, 7: 307-314.

Harvey, W.R., (1990). Users Guide for LSMLMW, Mixed Model Least Squares and Maximum Likelihood Computer Program. PC-2 Version. Ohio State University, Columbus, USA.

Khan, M.S, Z.M Rehman, A Khan and S Ahmad, (2008). Genetic resources and diversity in Pakistani cattle. Pakistan Veterinary Journal, 28: 95102

Khattab, A. S. and Sultan, Z. A. (1990). Estimates of phenotypic and genetic parameters for first lactation performance in Friesian cattle in Egypt. Egypt. J. Anim. Prod., 27(2): 147-160.

Khattab, A.S. and H. Atil, (1999). Genetic study of fertility traits and productive in a local born Friesian cattle in Egypt. Pak. J. Biol. Sci., 2: 1178-1183.

Oudah, E. Z. M. and Zainab A. Khalefa (2010). Genetic evaluation for Friesian Cattle in Egypt using single-trait animal models. J. Animal and Poultry Production, Mansoura University, Vol. 1 (9):371- 381

Oudah, E. Z. M.; Shalaby, N. A. and Mustafa, M. A. (2001). Genetic and nongenetic factors affecting days open, number of service per conception and age at first calving in a herd of Holstein-Friesian cattle. Pakistan Journal Biological Sciences, 4(6): 740-744. 
Oudah, E.Z.M., N.A. Shalaby and A.F.A. Mehrez, (2000). Genetic study on milk productive traits using first lactation records. Proceedings of the 3rd All Africa Conference on Animal Agriculture and 11th Conference of the Egyptian Society of Animal Production, Nov. 6-9, Egyptian Society of Animal Production, Faculty of Agriculture, Cairo University Egypt, pp: 73-79.

Sadek, R. R.; Helali, E. A.; Safwat, M. A.; Ibrahim, S. A. M. and Abd El-fatah, A. (1994). Evaluation of Friesian cattle performance in commercial farms in Egypt. Egypt. J. Anim. Prod., 31(1): 43-64.

Salem, A.Y. and E.M. Abdel-Raouf, (1999). Genetic study of fertility and productive traits in a commercial herd of Holstein-Friesian cattle in Egypt. J. Agric. Res. Tanta Univ., 25: 191-203.

Sattar, A. R .H, Mirza, A. A. K, Niazi and Latif M. (2005). Productive and reproductive performance of Holstein Friesian cows in Pakistan. Pakistan Vet. J., 25(2), 75-81.

Shalaby, N. A.; Oudah, E. Z. M. and Abdel-Momin, M. (2001). Genetic analysis of some productive and reproductive traits and sire evaluation in imported and locally born Friesian cattle raised in Egypt. Pakistan Journal Biological Sciences, 4(7): 893-901.

Shalaby, N.A. (2005). Genetic evaluation for milk production, reproduction traits and persistency of lactation using single- and two-trait animal model analyses for Friesian cows in commercial herds in Egypt. J, Agric. Sci., Mansoura Univ., 30(7): 3637-3654.

Skalicki Z and Latinovic D. (1990). The influences of bull-sires on productive and reproductive traits, variation of cows in the black and white cattle population. Dairy Sci. Abst., 52, 4611.

Snedecor, G.W. and W.G. Cochron, (1956). Statistical Methods Applied to Experiments in Agriculture and Biology. 5th Edn., low State University Press, Amess, low, pp: 73-78.

Swalve, H. and L.D. van Vleck, (1987). Estimation of genetic (Co) variances for milk yield in first three lactations using an animal model and restricted maximum likelihood. J. Dairy Sci., 70: 842-849.

Tadesse, M. J, J. Thiengtham, A. Pinyopummin. and S. Prasanpanich., (2010). Productive and reproductive performance of Holstein Friesian dairy cows in Ethiopia. Livestock Research for Rural Development, 22 (2) 2010 cited in http://www.lrrd.org//rrd22/2/tade22034.htm

Tag El-Dein, M.A., (1997). Phenotypic and genetic parameters of some performance traits in Friesian cattle. Ph.D. Thesis, Faculty of Agriculture, Alexandria University, Egypt. 
Shalaby, N. A. et al.

$$
\begin{aligned}
& \text { تحليـل وراثـي لبعض الصـفات الإنتاجيـة والتناسـلية لموسـم الحليب الأول للأبقـار }
\end{aligned}
$$

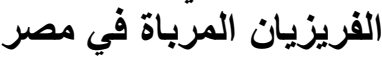

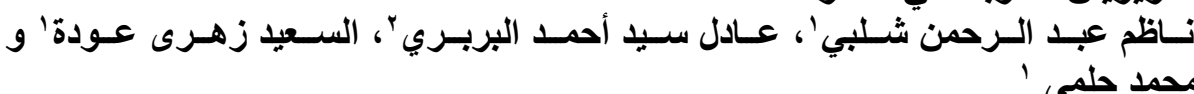

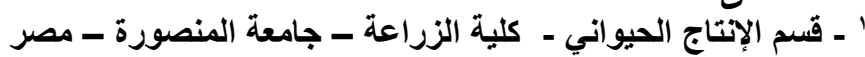

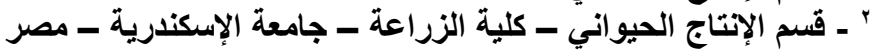

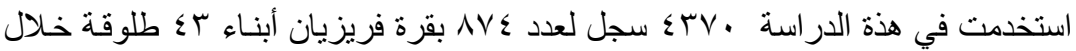

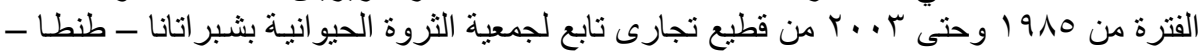

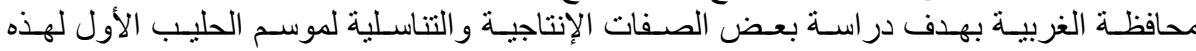

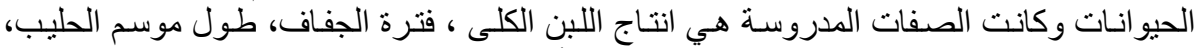

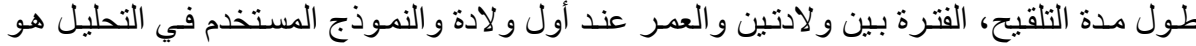

وكانت أهم النتائج المتحصل عليها هي:

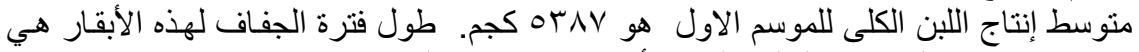

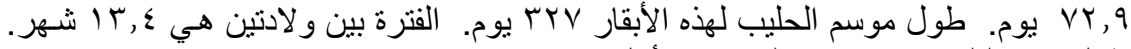

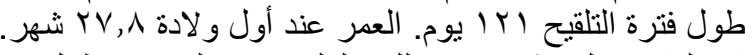

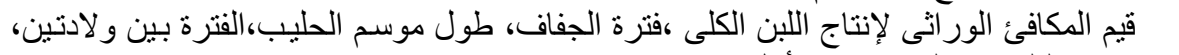

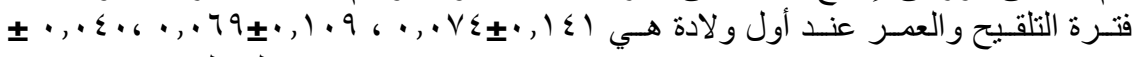

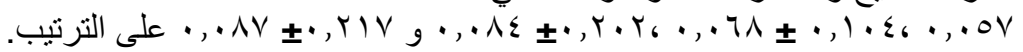

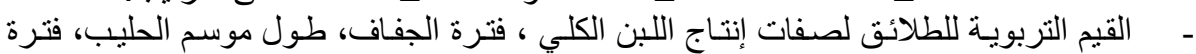

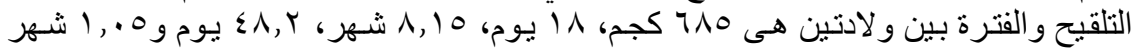
على الترتيب.

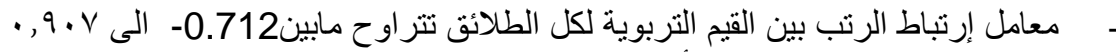

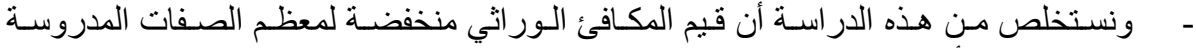
وبالتالى يجب أن تهتم المزرعة بالعو امل البيئية والرعاية اللازمـة لهذه القطعان لزيادة الإنتاج بصفة عامة.

كلية الزراعة - جامعة المنصورة كلية الزراعة - جامعة الاسكندرية
قام بتحكيم البحث أ. أد / محمد نجيب العريان أ.د / أدمد الطاهر مهذى الجيان 